University of Nebraska - Lincoln

DigitalCommons@University of Nebraska - Lincoln

8-1-1995

\title{
RED IMPORTED FIRE ANT IMPACTS ON NORTHERN BOBWHITE POPULATIONS
}

\author{
Craig R. Allen \\ University of Nebraska-Lincoln, callen3@unl.edu \\ R. Scott Lutz \\ Texas Tech University \\ Stephen Demarais \\ Texas Tech University, steve.demarais@msstate.edu
}

Follow this and additional works at: https://digitalcommons.unl.edu/usgsstaffpub

Part of the Earth Sciences Commons

Allen, Craig R.; Lutz, R. Scott; and Demarais, Stephen, "RED IMPORTED FIRE ANT IMPACTS ON NORTHERN BOBWHITE POPULATIONS" (1995). USGS Staff -- Published Research. 12.

https://digitalcommons.unl.edu/usgsstaffpub/12

This Article is brought to you for free and open access by the US Geological Survey at DigitalCommons@University of Nebraska - Lincoln. It has been accepted for inclusion in USGS Staff -- Published Research by an authorized administrator of DigitalCommons@University of Nebraska - Lincoln. 


\title{
RED IMPORTED FIRE ANT IMPACTS ON NORTHERN BOBWHITE POPULATIONS ${ }^{1}$
}

\author{
Craig R. Allen, ${ }^{2}$ R. Scott Lutz, and Stephen Demarais \\ Department of Range and Wildlife Management, Texas Tech University, Lubbock, Texas 79409-2125 USA
}

\begin{abstract}
The stability of Northern Bobwhite (Colinus virginianus) populations in Texas, where high density polygyne red imported fire ants (Solenopsis invicta) account for $>50 \%$ of all (S. invicta) colonies, has been cited as a reason to repudiate impacts by this exotic species on Northern Bobwhite. We used two approaches to investigate the relationship between red imported fire ants and Northern Bobwhite. In the first approach, we used correlation analysis to compare Northern Bobwhite abundance trends, determined from Christmas Bird Count data in 15 Texas counties, before and after fire ant infestation. Before red imported fire ant infestation, no significant trend in Bobwhite abundance existed $(r=$ $-0.355, P=0.314)$. After fire ant infestation, Northern Bobwhite abundance declined and was highly negatively correlated with years of infestation $(r=-0.867, P<0.001)$. Bobwhite populations from 16 uninfested counties in Texas revealed no trend over a $27-\mathrm{yr}$ (1966-1992) period $(r=-0.081, P=0.688)$. In the second approach, red imported fire ant populations were reduced on five 202-ha study areas in the Texas Coastal Bend; autumn Northern Bobwhite densities were monitored for $2 \mathrm{yr}$ on those reduced areas and five untreated areas. By the 2nd yr, Bobwhite autumn density was higher $(P=0.028)$ on areas where red imported fire ants were suppressed. We concluded that polygyne red imported fire ants were negatively impacting Northern Bobwhite in this region of Texas.
\end{abstract}

Key words: Colinus virginianus; exotic species impacts; Northern Bobwhite population trends; polygyne; red imported fire ant; Solenopsis invicta; Texas Coastal Bend.

\section{INTRODUCTION}

Red imported fire ants (Solenopsis invicta) are native to areas along the Paraguay and Parana Rivers of South America. S. invicta was accidentally introduced to the United States around 1930, at the port of Mobile, Alabama (Vinson and Sorensen 1986). S. invicta spread rapidly from the vicinity of Mobile and, by the early 1980s, occupied most of Mississippi, Louisiana, Florida, Georgia, and South Carolina, and parts of North Carolina, Tennessee, Arkansas, Oklahoma, and Texas (Canter 1981). Average minimum temperatures of $<-12^{\circ} \mathrm{C}$ probably limit the establishment of $S$. invicta in the northern United States (Vinson and Sorensen 1986).

In 1973, researchers in Mississippi discovered a population of $S$. invicta with multiple fertile queens present in all colonies (Glancey et al. 1973). These polygyne fire ants lack intraspecific territoriality and may occur at extremely high densities (Glancey and Lofgren 1988). Monogyne red imported fire ants generally stabilize at densities of $\leq 99$ mounds/ha, but polygyne fire ants generally occur at densities $>198$ mounds/ha, and infestations as high as 5930 mounds/ha have been recorded (H. Collins, USDA, APHIS, personal commu-

\footnotetext{
' Manuscript received 29 November 1993; revised 10 September 1994; accepted 17 October 1994; final version received 3 November 1994.

${ }^{2}$ Present address; Florida Cooperative Fish and Wildlife Research Unit, 117 Newins-Ziegler Hall, University of Florida, Gainesville, Florida 31611-0450.
}

nication). Polygyne fire ants appear to have become more common since their discovery (Glancey et al. 1987), but expansion in Florida and Louisiana is either very slow or at equilibrium (Porter 1993). In Texas, $>50 \%$ of all colonies are polygyne (Porter et al. 1991).

Red imported fire ants outcompete or prey upon a number of invertebrates (Burns and Melancon 1977, Morrill 1978, Summerlin and Kunz 1978, Fillman and Sterling 1983, Roth et al. 1983). They also reduce invertebrate community diversity (Porter et al. 1988, Porter and Savignano 1990) and decrease volumetric indices of insect biomass and abundance (Allen 1993).

Fire ants were first reported as a source of mortality in birds by Travis $(1938 a, b)$, who reported a $6.5 \%$ loss of pipping Northern Bobwhite to a native fire ant, $S$. geminata. A $6 \%$ mortality of pipping Northern Bobwhite chicks was observed by Johnson (1961), yet he concluded that fire ants had little impact on Northern Bobwhite populations. Johnson's observations were of monogyne black imported fire ants (S. richteri) at relatively low densities (51 mounds/ha). Dewberry (1962) observed a $12 \%$ pipping chick mortality under the same biological conditions as Johnson (1961). Other research documented lower impact (e.g., Simpson 1976). An overview of fire ant impacts on wildlife, including Northern Bobwhite, may be found in Allen et al. (1994). Past research concerning fire ant impacts on quail was conducted in areas infested with either native fire ants or monogyne black imported fire ants, which have been subsequently outcompeted and displaced by $S$. invicta. Nevertheless, several of these studies doc- 
umented a potentially significant impact. We believe past research has done little to answer questions concerning the impact of $S$. invicta on Northern Bobwhite populations, but authors interpret these results differently (Allen et al. 1993, Brennan 1993).

Northern Bobwhite have been declining in almost all regions within their range in the United States (Droege and Sauer 1990). This decline is more severe in the Southeast than in the Midwest or Northeast (Brennan 1991). Previous work that used correlation analysis to investigate trends in Northern Bobwhite abundance over time indicated that trends were positive only in Texas and Nebraska (Brennan 1991) or Texas and Oklahoma (Droege and Sauer 1990). We re-analyzed the annual changes in Texas breeding bird survey data (Droege and Sauer 1990) and found a difference $(P=$ 0.01 , Mann-Whitney test) in the slopes of the regression lines representing Northern Bobwhite population trends between regions in Texas infested $(m=-2.37)$ and uninfested $(m=+2.29)$ by $S$. invicta. Given the results of our analysis of breeding bird surveys and the prevalence of polygyne $S$. invicta in Texas, we investigated long-term population trends of Northern Bobwhite before and after $S$. invicta infestation in Texas. Additionally, we monitored the response of Northern Bobwhite to experimental reduction of $S$. invicta populations in a field experiment.

\section{STUdy AREA}

Field research was conducted on 10 study areas (five pairs: R1, R2, V1, VC1, and VC2) in Refugio, Victoria, and Calhoun Counties in the Texas Coastal Bend. Each study area was $\approx 202$ ha. The $\mathrm{R} 1$ pair was located in Refugio County and soils were clayey loams; distance between sites was $\approx 2.4 \mathrm{~km}$. The R2 pair was located in Refugio County, with areas separated by $10.4 \mathrm{~km}$; soils were clayey and sandy loams. The V1 pair was located in Victoria County, soils were clayey to sandy loam, and distance between areas was $\approx 3.2 \mathrm{~km}$. The VC1 pair members, on heavy clay, were separated by $\approx 16 \mathrm{~km}$; the treated area was located in Victoria and the untreated area in Calhoun County. The VC2 pair was on sandy loams, separated by $\approx 8 \mathrm{~km}$ and on opposite sides of the Guadalupe River; the treated area was in Calhoun and the untreated in Victoria County. These VC2 study areas were rolling and well drained; all other sites had $<3 \%$ slope and were poorly drained.

Climate for this entire area is humid subtropical. Rainfall for Victoria (central to all study areas) averages $97 \mathrm{~cm} / \mathrm{yr}$ (Miller 1979). Rainfall peaks occur in May, June, and September, with $>11 \mathrm{~cm}$ falling during these months, on average. Yearly maximum and minimum average temperatures are $27^{\circ} \mathrm{C}$ and $16^{\circ} \mathrm{C}$, respectively (Miller 1979).

All study areas were located on active private cattle ranches. Vegetation was typical for grazed rangeland of the Coastal Bend gulf prairies, and brush cover on these areas ranged from 7 to $40 \%$. Refugio County study areas were continuously grazed at the average stocking rate of $5.3 \mathrm{ha} / \mathrm{cow}$. Other study areas were rotationally grazed at slightly higher stocking rates. Herbaceous species composition and relative abundance and percent brush cover for the study areas are listed in Allen (1993).

\section{METHODS}

\section{Long-term Bobwhite population trends}

Northern Bobwhite Quail abundance was investigated using indices of abundance available for 19661992 in 15 Texas counties (Christmas Bird Counts, available in American Birds). All infested physiographic regions of Texas (Droege and Sauer 1990) were represented in this sample. These counties provided $\geq 4$ yr of data both prior to and after $S$. invicta infestation. Dates of infestation in these counties were determined with U.S.D.A. quarantine maps, and varied widely (1972-1987). Northern Bobwhite abundance was determined by dividing total Bobwhites observed during Christmas Bird Counts by observer hours (number of observers multiplied by party hours; Brennan 1991).

Data were analyzed for correlation between abundance and year prior to infestation, and abundance and year post-infestation. Abundance was determined for each year prior to or after infestation, averaging across all counties. A minimum of five counties was used to determine average abundance; this provided $10 \mathrm{yr}$ of usable data prior to infestation and $20 \mathrm{yr}$ post-infestation. Given the wide variation in infestation dates, pre-infestation trend provided a comparison for postinfestation trend. As another comparison, 16 counties providing $27 \mathrm{yr}$ of data from uninfested regions of Texas were correlated against time to further test for simple time effects. Finally, the average Northern Bobwhite abundance was determined for each county before and after fire ant infestation; differences were analyzed with a paired $t$ test.

\section{Manipulative research}

Study areas $(n=10)$ were paired based on soil and vegetation similarities, spring 1991 Northern Bobwhite whistle counts (Allen 1993), and indices of S. invicta abundance. To reduce red imported fire ant populations, one member of each study area pair was chosen randomly and treated with AMDRO fire ant bait (American Cyanamid Company, Wayne, New Jersey) at the average rate of $1.67 \mathrm{~kg} / \mathrm{ha}$ in April and October 1991, and May 1992. Fire ant populations were monitored using 10 0.10-ha non-overlapping circle counts (Lofgren and Williams 1982) per study area, repeated seven times post-treatment. This provided an index of $S$. invicta populations that was sensitive to the presence or absence of an immature worker caste. Lack of immatures indicates absence of a fertile queen(s) within a mound, identifying a moribund colony. Polygyny was determined by floating excavated mounds in the lab- 


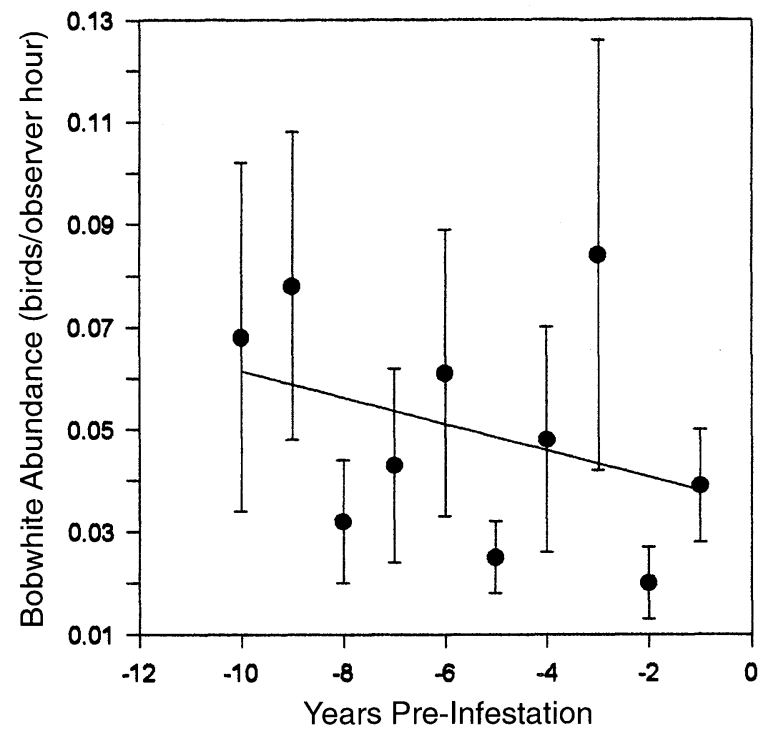

FIG. 1. Northern Bobwhite abundance (quail/observer hours) trend in 15 Texas counties before red imported fire ant infestation (quarantine). Abundance based on Christmas Bird Count data. Error bars represent \pm 1 SE.

oratory, collecting floated queen(s) from the mound, and dissecting queens to determine if insemination had occurred. Efficacy of treatments was analyzed with randomized block design analysis of variance, with pretreatment fire ant levels used as a covariate (SAS Institute 1989).

Bobwhite densities were determined with line transects (Guthery 1988) from 6 September to 31 October of 1991 and 1992. Permanent transects of $\approx 3.2 \mathrm{~km}$ were established on each study area and were walked within $3 \mathrm{~h}$ of sunrise and/or sunset until a minimum distance of $29 \mathrm{~km}$ was attained. We measured perpendicular distance to flushed coveys and recorded covey size. The Fourier series model of Program TRANSECT (Burnham et al. 1980) produced a density estimate for each area. We used the Fourier series detection model for ungrouped perpendicular distances due to its model robustness, pooling robustness, efficiency, fit to shape criterion, and performance with small samples. In 1992, data from study area VC1 untreated were grouped because of the non-normal distribution of observed perpendicular distances. Density estimates were analyzed with randomized block design ANOVA (SAS Institute 1989). Additionally, Northern Bobwhite abundance was indexed with spring whistle counts (Schemnitz 1980) prior to treatment in spring 1991, and again in 1992. Indices on treated and untreated areas were compared using randomized block design ANOVA. Logistical limitations of population-level studies limit the number of replicated study areas; because of the limited number of replicates, differences between means were considered to have biological significance at $P<0.10$ (Tacha et al. 1982).

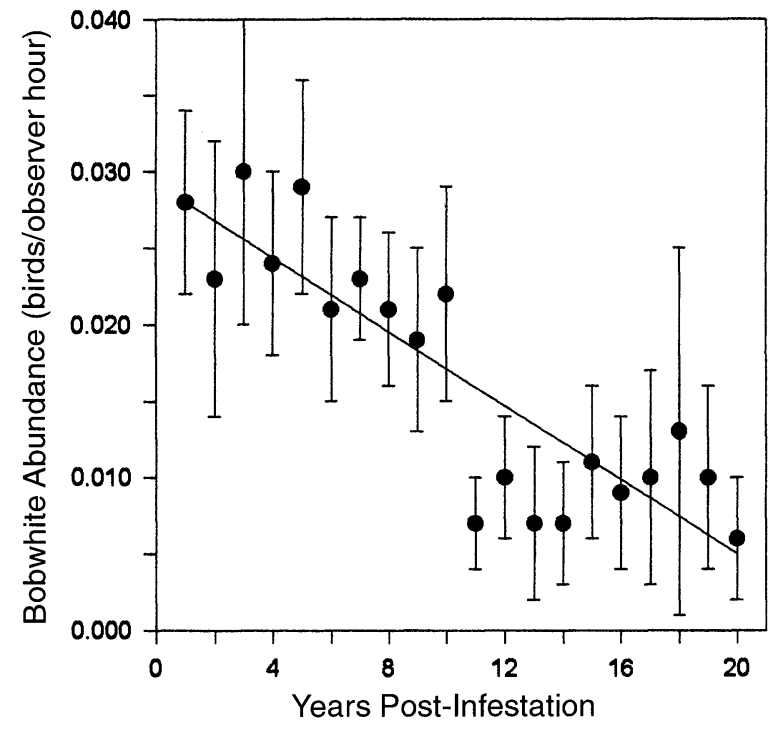

FIG. 2. Northern Bobwhite abundance (quail/observer hours) trend in 15 Texas counties after red imported fire ant infestation (quarantine). Abundance based on Christmas Bird Count data. Error bars represent \pm 1 SE.

\section{RESULTS}

\section{Long-term Bobwhite population trends}

Prior to infestation by $S$. invicta, there was no significant trend over time in Northern Bobwhite abundance $(r=-0.335, P=0.314)$ for the 15 counties in the study (Fig. 1). After infestation, Northern Bobwhite abundance declined ( $r=-0.867, P<0.001$; Fig. 2). Average Northern Bobwhite abundance was $>100 \%$ higher before than after infestation in the 15 counties $(P=0.009, \mathrm{df}=14$; Table 1$)$. There was no significant trend ( $r=0.081, P=0.668$; Fig. 3 ) in Bobwhite abun-

TABLE 1. Average Northern Bobwhite abundance estimated using Christmas Bird Counts in 15 Texas counties before and after red imported fire ant infestation. Sample size (years of data) indicated in parentheses.

\begin{tabular}{lclc}
\hline \hline & & \multicolumn{2}{c}{$\begin{array}{c}\text { Average abundance } \\
\text { (birds/observer hours) }\end{array}$} \\
\cline { 3 - 4 } \multicolumn{1}{c}{ County } & $\begin{array}{c}\text { Year of } \\
\text { infestation }\end{array}$ & $\begin{array}{c}\text { Before } \\
\text { infestation }\end{array}$ & $\begin{array}{c}\text { After } \\
\text { infestation }\end{array}$ \\
\hline Bexar & 1972 & $0.045(6)$ & $0.031(20)$ \\
Bowie & 1986 & $0.041(20)$ & $0.015(6)$ \\
Brazoria & 1972 & $0.013(6)$ & $0.003(20)$ \\
Brazos & 1975 & $0.010(9)$ & $0.007(17)$ \\
Burnet & 1987 & $0.102(13)$ & $0.010(5)$ \\
Dallas & 1972 & $0.020(6)$ & $0.008(20)$ \\
Denton & 1972 & $0.009(6)$ & $0.032(20)$ \\
Fannin & 1987 & $0.097(11)$ & $0.033(5)$ \\
Kendall & 1975 & $0.016(8)$ & $0.018(17)$ \\
McLennan & 1984 & $0.113(10)$ & $0.030(8)$ \\
Nueces & 1975 & $0.032(9)$ & $0.009(17)$ \\
San Patricio & 1975 & $0.041(9)$ & $0.039(17)$ \\
Smith & 1975 & $0.049(9)$ & $0.027(17)$ \\
Tarrant & 1983 & $0.027(17)$ & $0.012(9)$ \\
Walker & 1972 & $0.045(6)$ & $0.010(20)$ \\
Average & & 0.044 & 0.019
\end{tabular}




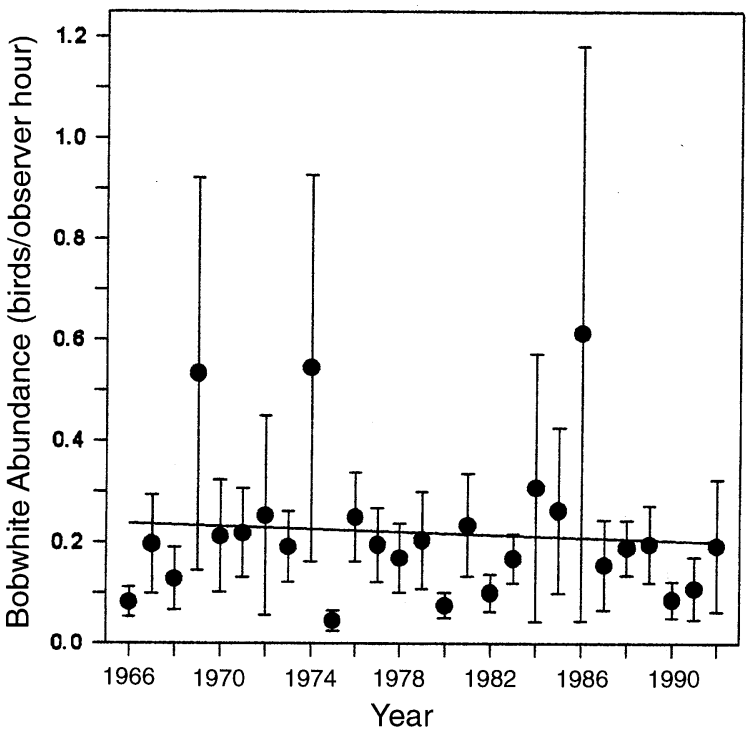

FIG. 3. Northern Bobwhite abundance (quail/observer hours) trend for 1966-1992 in 16 Texas counties outside the area of red imported fire ant infestation (quarantine). Abundance based on Christmas Bird Count data. Error bars represent $\pm 1 \mathrm{SE}$.

dance between 1966 and 1992 in 16 counties never invaded by $S$. invicta.

\section{Manipulative research}

Red imported fire ants present on study areas were predominately polygyne, with the exception of VC1, where polygyne $S$. invicta were not detected. S. invicta population indices declined following treatments (Table 2). S. invicta indices on treated and untreated areas differed during Bobwhite reproductive periods. In June 1991, S. invicta indices on treated sites were reduced by $81 \%$ and were $70 \%$ lower than indices on untreated sites $(P=0.067)$. In March and June 1992, indices on treated sites were reduced $69 \%$ and $95 \%$, respectively, from pre-treatment levels, and were lower than indices on untreated sites $(P=0.055$ and $P=0.062$; Table 2). Reduction was essential during the peak periods of Bobwhite reproduction, 16 May-15 June (Simpson
1972), as the literature indicated that fire ants could impact pipping young.

No differences were detected in Northern Bobwhite densities during autumn 1991 following one treatment $(P=0.33$; Table 3$)$. Average density in 1991 was 4.35 Bobwhite/ha on treated areas and 1.33/ha on untreated areas. Significant differences in Northern Bobwhite densities were detected in 1992, following three $S$. invicta population reductions $(P=0.028)$. In 1992 , Bobwhite densities averaged 2.09 Bobwhite/ha on treated areas and 0.85 Bobwhite/ha on untreated areas (Table $3)$. Northern Bobwhite whistle counts pre-treatment did not differ $(P=0.52)$. In 1991 , after two $S$. invicta population reductions, whistle count indices of Northern Bobwhite abundance were higher on treated areas (2.5 Bobwhite per stop vs. 1.9 Bobwhite per stop; $P$ $=0.063)$.

\section{DISCUSSION}

Our research provides two lines of evidence that Northern Bobwhite may be negatively impacted by $S$. invicta. First, our analysis of long-term quail indices revealed that the length of time a county was infested with $S$. invicta explained $75 \%$ of the observed variation in Northern Bobwhite abundance after invasion by $S$. invicta. The significant relationship after infestation was present despite widely varied infestation dates and absence of significant population trends before infestation. In our field experiments, we also detected a negative influence: densities of Northern Bobwhites increased on areas treated to reduce $S$. invicta populations. We were surprised at finding differences in Bobwhite densities, given our small number of replicates and the short duration of our experiments. We calculated the statistical power of our comparison of Bobwhite densities on treated and untreated sites in 1991 at $<0.50$. The difference detected in our 1992 experiment may have been the result of better fire ant control achieved in the spring of that year or cumulative effect of the series of three treatments. Our manipulative experiment was brief; however, during Northern Bobwhite surveys conducted in autumn 1993 (16 mo posttreatment), we detected no difference $(P=0.66)$ in

TABLE 2. Average indices of red imported fire ant abundance from 100.10 -ha circle counts per study area on five pairs of treated and untreated study areas in the Texas Coastal Prairie, pre-treatment and during seven post-treatment counts, 19911992. Means have been adjusted by use of a covariate (pre-treatment indices).

\begin{tabular}{|c|c|c|c|c|c|}
\hline \multirow[b]{2}{*}{ Date } & \multicolumn{2}{|c|}{ Treated } & \multicolumn{2}{|c|}{ Untreated } & \multirow[b]{2}{*}{$P$-level } \\
\hline & $\bar{X}$ & SE & $\bar{X}$ & SE & \\
\hline Pre-treatment (April 1991) & 435 & 43 & 297 & 30 & 0.230 \\
\hline June 1991 & 60 & 16 & 201 & 17 & 0.067 \\
\hline July & 126 & 28 & 153 & 20 & 0.711 \\
\hline October & 262 & 36 & 335 & 22 & 0.561 \\
\hline January 1992 & 31 & 24 & 522 & 56 & 0.078 \\
\hline March & 63 & 29 & 551 & 49 & 0.055 \\
\hline June & 11 & 10 & 289 & 25 & 0.062 \\
\hline August & 13 & 8 & 132 & 18 & 0.214 \\
\hline Average, post-treatment & 81 & 34 & 312 & 64 & \\
\hline
\end{tabular}


TABLE 3. Estimates of Northern Bobwhite densities (Fourier series, Program TRANSECT) on five pairs of treated and untreated 202-ha study areas in the Texas Coastal Bend, 1991-1992. $N$, total number of coveys flushed on a line of length $L(\mathrm{~km}) ; C$, average covey size, adults and subadults; $\hat{C}$, estimated number of coveys/ha; $\hat{D}$, estimated Bobwhite density, in numbers/ha.

\begin{tabular}{lcrrrrrr}
\hline \hline Study area & Year & $N$ & \multicolumn{1}{c}{$L$} & \multicolumn{1}{c}{$C$} & $\hat{C}$ & \pm 1 SE & $\hat{D}$ \\
\hline R1 Treated & 1991 & 46 & 30.42 & 10.7 & 1.4150 & 0.277 & 15.14 \\
& 1992 & 24 & 74.83 & 8.1 & 0.1513 & 0.040 & 1.23 \\
R1 Untreated & 1991 & 12 & 28.00 & 9.0 & 0.1419 & 0.097 & 1.28 \\
& 1992 & 7 & 51.71 & 7.6 & 0.0161 & 0.021 & 0.12 \\
R2 Treated & 1991 & 31 & 40.55 & 10.5 & 0.2704 & 0.060 & 2.84 \\
& 1992 & 32 & 58.58 & 7.9 & 0.6213 & 0.154 & 4.91 \\
R2 Untreated & 1991 & 21 & 38.62 & 13.0 & 0.2607 & 0.111 & 3.39 \\
& 1992 & 29 & 50.21 & 6.7 & 0.3750 & 0.156 & 2.51 \\
V1 Treated & 1991 & 21 & 33.25 & 8.8 & 0.2786 & 0.076 & 2.45 \\
& 1992 & 29 & 70.00 & 10.3 & 0.2416 & 0.053 & 2.49 \\
V1 Untreated & 1991 & 12 & 45.91 & 11.4 & 0.1205 & 0.051 & 1.37 \\
& 1992 & 17 & 88.99 & 7.6 & 0.1219 & 0.037 & 0.93 \\
VC1 Treated & 1991 & 18 & 53.11 & 9.9 & 0.0939 & 0.030 & 0.93 \\
& 1992 & 31 & 115.80 & 7.5 & 0.1607 & 0.037 & 1.21 \\
VC1 Untreated & 1991 & 9 & 31.03 & 7.0 & 0.0848 & 0.028 & 0.59 \\
VC2 Treated & 1992 & 15 & 76.25 & 7.7 & 0.0336 & 0.033 & 0.26 \\
& 1991 & 4 & 34.72 & 9.0 & 0.0417 & 0.021 & 0.38 \\
VC2 Untreated & 1992 & 15 & 90.91 & 7.1 & 0.0852 & 0.030 & 0.60 \\
& 1991 & 0 & 31.52 & & 0.0000 & & 0.00 \\
& 1992 & 7 & 69.92 & 10.6 & 0.0410 & 0.016 & 0.43 \\
\hline
\end{tabular}

Bobwhite densities on treated and untreated sites (R. S. Lutz, unpublished data). Given that S. invicta infestation at the county level may take $\geq 20 \mathrm{yr}$ (Wojcik 1994), we interpreted our correlations and experimental evidence to suggest $S$. invicta may be an additional factor depressing Northern Bobwhite populations in this region of Texas.

Our analysis suggests that Northern Bobwhite population trends are not stable throughout Texas, as suggested by past research (Droege and Sauer 1990, Brennan 1991). Instead, our data suggest that Northern Bobwhite populations are decreasing in areas infested by $S$. invicta, but may be stable or increasing in uninfested regions.

The observation of few Northern Bobwhite on some study areas decreased the precision of some density estimates. Low sample size was a more pronounced problem on untreated study areas. Limited replications resulted in a low statistical power for field data. Because our Type II error rate in 1991 was high, rejection of the null of no difference between treatments was more difficult (Alldredge and Ratti 1986).

Our goal was to investigate the possible link between fire ants and Northern Bobwhite. Unfortunately, we have little evidence on the processes involved. We do know that fire ants are attracted to moist (mucous) membranes (Vinson and Sorensen 1986); and pipping eggs are very attractive to S. invicta. However, the pipping stage is not necessarily the only life history period vulnerable to $S$. invicta impact. Indirect impacts may occur through a decrease in quantity of insects available. Fire ants negatively impact arthropod communities (Porter and Savignano 1990) and decrease indices of insect biomass (Allen 1993). Insects are an important food source for Northern Bobwhite young during their first 2 wk of life (Hurst 1972), and may fulfill the higher nutritional requirements of female quail during reproductive periods (Case 1982). We did not address the issue of competition for seeds, but $S$. invicta does alter insect community composition. This perturbation has potential impact on other granivores within and between trophic levels (Davidson et al. 1985). Additionally, young chicks experience decreased weight gain after exposure to non-lethal doses of S. invicta venom (C. R. Allen, unpublished data).

Solenopsis invicta is unlikely to be the exclusive factor responsible for the recent observed decline in Northern Bobwhite abundance. Large-scale changes in farming and silvicultural practices, as well as a poor understanding of the impact of harvest and the direct and indirect impact of pesticides on Bobwhite, have been proposed as explanations for declines in quail populations (Brennan 1991). However, land management practices leading to soil and vegetation disturbance are likely to increase $S$. invicta populations. $S$. invicta is one of many threats to Northern Bobwhite populations, but in areas with high levels of infestation, the threat is real.

In the past, Bobwhite population dynamics in arid and semiarid environments were linked to precipitation (Lehmann 1953, Kiel 1976, Giuliano and Lutz 1993). More recently, a precipitation-habitat model (Rice et al. 1993) was used to predict autumn density of Northern Bobwhite. We noted that the precipitation-habitat model performed poorly in predicting Northern Bobwhite abundance in the Gulf Coastal Prairies of Texas, an area of heavy $S$. invicta infestation. Our results suggest that red imported fire ant abundance in arid and 
semiarid habitats may also be an important factor in Northern Bobwhite population dynamics. We encourage other biologists to investigate the impact of $S$. invicta on vertebrates in other ecosystems, for longer time periods.

\section{ACKNOWLEDGMENTS}

We thank the following organizations for their cooperation: American Cyanamid, Houston Livestock Show, Quail Unlimited, Texas Department of Agriculture, Texas Department of Parks and Wildlife, United States Department of Agriculture, and the Welder Wildlife Foundation. Data collection was aided by P. Allen, G. Klockars, and T. Monasmith. W. Giuliano, E. Laca, and L. Smith reviewed our manuscript. This is publication T-9-669 of the Texas Tech University College of Agricultural Sciences and Natural Resources, and Welder Wildlife Foundation contribution 441.

\section{Literature Cited}

Alldredge, J. R., and J. T. Ratti. 1986. Comparison of some statistical techniques for analysis of resource selection. Journal of Wildlife Management 50:157-165.

Allen, C. R. 1993. The response of wildlife to red imported fire ant population reductions in the Texas coastal plain. Thesis. Texas Tech University, Lubbock, Texas, USA.

Allen, C. R., R. S. Lutz, and S. Demarais. 1993. What about fire ants and Northern Bobwhites? Wildlife Society Bulletin 21:349-351.

Allen, C. R., S. Demarais, and R. S. Lutz. 1994. Red imported fire ant impacts on wildlife: an overview. Texas Journal of Science 46:51-59.

Brennan, L. A. 1991. How can we reverse the Northern Bobwhite population decline? Wildlife Society Bulletin 19: 544-555.

1993. Fire ants and Northern Bobwhites: a real problem or a red herring? Wildlife Society Bulletin 21:351355.

Burnham, K. P., D. R. Anderson, and J. L. Laake. 1980. Estimation of density from line transect sampling of biological populations. Wildlife Monograph 72:1-202.

Burns, E. C., and D. G. Melancon. 1977. Effect of imported fire ant (Hymenoptera: Formicidae) invasion on lone star tick (Acarina: Ixodidae) populations. Journal of Medical Entomology 14:247-249.

Canter, L. W. 1981. Final programmatic environmental impact statement. U.S.D.A., APHIS-ADM-81-01-F, Hyattsville, Maryland.

Case, R. M. 1982. Adaptations of female Bobwhite to energy demands of the reproductive cycle. Proceedings of the National Bobwhite Quail Symposium 2:74-78.

Davidson, D. W., D. A. Samson, and R. S. Inouye. 1985. Granivory in the Chihuahuan desert: interactions within and between trophic levels. Ecology 66:486-502.

Dewberry, O. 1962. Fire ant control investigations. Federal Aid in Fish and Wildlife Restoration Project W-37-R-1-2, Georgia, USA.

Droege, S., and J. R. Sauer. 1990. Northern Bobwhite, Gray Partridge, and Ring-necked Pheasant population trends (1966-1988) from the North American Breeding Bird Survey. Pages 2-20 in K. E. Church, R. E. Warner, and S. J. Brady, editors. Perdix V: Gray Partridge and Ring-necked Pheasant workshop. Kansas Department of Wildlife and Parks, Emporia, Kansas, USA.

Fillman, D. A., and W. L. Sterling. 1983. Killing power of the red imported fire ant (Hym.: Formicidae): a key predator of the boll weevil (Col.: Curculioinidae). Entomophaga 28: 339-344.

Giuliano, W. M., and R. S. Lutz. 1993. Quail and rain: what's the relationship? Proceedings of the National Bobwhite Quail Symposium 3:64-68.
Glancey, B. M., C. H. Craig, C. E. Stringer, and P. M. Bishop. 1973. Multiple fertile queens in colonies of the imported fire ant, Solenopsis invicta. Journal of the Georgia Entomologial Society 8:237-238.

Glancey, B. M., and C. S. Lofgren. 1988. Adoption of newly mated queens: a mechanism for proliferation and perpetuation of polygynous red imported fire ants, Solenopsis invicta Buren. Florida Entomologist 71:581-587.

Glancey, B. M., J. C. E. Nickerson, D. Wojcik, J. Trager, W. A. Banks, and C. T. Adams. 1987. The increasing incidence of the polygynous form of the red imported fire ant, Solenopsis invicta (Hymenoptera: Formicidae), in Florida. Florida Entomologist 68:162-168.

Guthery, F. S. 1988. Line transect sampling of Bobwhite density on rangelands: evaluation and recommendations. Wildlife Society Bulletin 16:193-203.

Hurst, G. A. 1972. Insects and Bobwhite Quail management. Proceedings of the National Bobwhite Quail Symposium 1:65-82.

Johnson, A. S. 1961. Antagonistic relationships between ants and wildlife with special reference to imported fire ants and Bobwhite Quail in the Southeast. Proceedings of the Annual Conference of Southeastern Association Game and Fish Commissioners 15:88-107.

Kiel, W. H., Jr. 1976. Bobwhite Quail population characteristics and management implications in south Texas. Transactions of the North American Wildlife Conference 41: 407-420.

Lehmann, V. W. 1953. Bobwhite population fluctuations and vitamin A. Transactions of the North American Wildlife Conference 18: 199-246.

Lofgren, C. S., and D. F. Williams. 1982. Avermectin $\mathrm{B}_{1} \mathrm{a}$ : highly potent inhibitor of reproduction by queens of the red imported fire ant (Hymenoptera: Formicidae). Journal of Economic Entomology 75:798-803.

Miller, W. L. 1979. Soil survey of Victoria county, Texas. U.S.D.A., Soil Conservation Service, Washington, D.C., USA.

Morrill, W. L. 1978. Red imported fire ant predation on the alfalfa weevil and pea aphid. Journal of Economic Entomology 71:867-868.

Porter, S. D. 1993. Stability of polygyne and monogyne fire ant populations (Hymenoptera: Formicidae: Solenopsis invicta) in the United States. Journal of Economic Entomology 86:1344-1347.

Porter, S. D., A. Bhatkar, R. Mulder, S. B. Vinson, and J. D. Clair. 1991. Distribution and density of polygyne fire ants (Hymenoptera: Formicidae) in Texas. Journal of Economic Entomology 84:866-874.

Porter, S. D., and D. A. Savignano. 1990. Invasion of polygyne fire ants decimates native ants and disrupts arthropod community. Ecology 71:2095-2106.

Porter, S. D., B. Van Eimeren, and L. E. Gilbert. 1988. Invasion of red imported fire ants (Hymenoptera: Formicidae): microgeography of competitive replacement. Annals of the Entomological Society of America 81:913-918.

Rice, S. M., F. S. Guthery, G. S. Spears, S. J. DeMaso, and B. H. Koerth. 1993. A precipitation-habitat model for Northern Bobwhites on semiarid rangeland. Journal of Wildlife Management 57:92-102.

Roth, J. P., G. T. Fincher, and J. W. Summerlin. 1983. Competition and predation as mortality factors of the horn fly, Haematobia irritans (Diptera: Muscidae), in a central Texas pasture habitat. Environmental Entomology 12:106-109.

SAS Institute. 1989. SAS/STAT user's guide, version 6 . Fourth edition. SAS Institute, Cary, North Carolina, USA.

Schemnitz, S. D., editor. 1980. Wildlife management techniques manual. Fourth edition. Wildlife Society, Washington, D.C., USA.

Simpson, R. C. 1972. A study of Bobwhite Quail nest ini- 
tiation dates, clutch sizes, and hatch sizes in southwest Georgia. Proceedings of the National Bobwhite Quail Symposium 1:199-204.

- 1976. Certain aspects of the Bobwhite Quail's life history and population dynamics in southwest Georgia. Georgia Department of Natural Resources Technical Bulletin WL-1.

Summerlin, J. W., and S. E. Kunz. 1978. Predation of red imported fire ant on stable flies. Southwestern Entomologist 3:260-262.

Tacha, T. C., W. D. Wade, and K. P. Burnham. 1982. Use and interpretation of statistics in wildlife journals. Wildlife Society Bulletin 10:355-362.
Travis, B. V. 1938a. The fire ant (Solenopsis spp.) as a pest of quail. Journal of Economic Entomology 31:649-652.

$1938 b$. Fire ant problem in the Southeast with special reference to quail. Transactions of the North American Wildlife Conference 3:705-708.

Vinson, S. B., and A. A. Sorensen. 1986. Imported fire ants: life history and impact. Texas Department of Agriculture, Austin, Texas, USA.

Wojcik, D. P. 1994. Impact of the red imported fire ant on native ant species in Florida. Pages 269-281 in D. F. Williams, editor. Exotic ants: biology, impact, and control of introduced species. Westview Press, Boulder, Colorado, USA. 